\title{
Evaluation of AutoLab Rapid Plasma Reagin and AutoLab Treponema pallidum Latex Agglutination for Syphilis Infection Testing
}

\author{
Mi-Jung Park, \\ Pil-Whan Park, \\ Yiel-Hea Seo, \\ Jeong-Yeal Ahn, \\ Kyung-Hee Kim, \\ Ja-Young Seo, Ji-Hun \\ Jeong, Moon Jin Kim, \\ and Hwan Tae Lee \\ Department of Laboratory \\ Medicine, Gachon \\ University Gil Medical \\ Center, Gachon University, \\ Incheon, Korea
}

Corresponding author: Pil-Whan Park Department of Laboratory Medicine, Gachon University Gil Medical Center, Gachon University, 21 Namdong-daero 774beon-gil, Namdong-gu, Incheon 405-760, Korea Tel: +82-32-460-3834 Fax: +82-32-460-3415 E-mail:pwpark@gilhospital.com pISSN: 1225-097X eISSN: 2288-7261
Background: Automated assays have recently been developed for efficient serological testing of syphilis infection. Here, we evaluate the performance of new automated serological assays for syphilis infection.

Methods: The precision, linearity, and detection limit of the automated kits AutoLab rapid plasma reagin (RPR) (IVD-RPR) and AutoLab (Treponema pallidum Latex Agglutination) TPLA (IVD-TPLA) (IVDLab Co., Korea) were evaluated using an immunoturbidimetric method. In addition, the results of these tests were compared with those obtained using the HiSens Auto RPR LTIA (HBi-RPR) and HiSens Auto TP LTIA (HBi-TPLA) tests (HBi Co., Korea) with 122 serum samples.

Results: Both the IVD-RPR and IVD-TPLA kits showed acceptable precision for the positive controls (IVDLab Co., Korea). The within-run and total precision of IVD-RPR were better than those of HBi-RPR at cut-off levels (CV, 7.0\% to 7.4\% for IVD-RPR; CV, 33.3\% to $40.0 \%$ for HBi-RPR). The IVD-RPR and IVD-TPLA kits demonstrated acceptable linearity and limits of detection. The agreement rate between IVD-RPR and HBi-RPR was $83.60 \%$ $(102 / 122)$. Nineteen samples were IVD-RPR negative but HBi-RPR positive; 12 of these were from patients with a history of syphilis. The agreement rate between IVD-TPLA and HBiTPLA was $96.72 \%$ (118/122). All discrepant results were IVD-TPLA positive and HBi-TPLA negative.

Conclusions: IVD-RPR and IVD-TPLA exhibited acceptable precision, linearity, and limits of detection for the diagnosis of syphilis infection. IVD-RPR was suitable for monitoring syphilis infections with good precision that was near cut-off levels. IVD-TPLA was useful for detecting primary syphilis infection.

(J Lab Med Qual Assur 2015;37:29-36)

Key Words: Rapid plasma reagin, Treponema pallidum latex agglutination, Syphilis

Received October 17, 2014, Revision received January 13, 2015, Accepted February 3, 2015

\section{서론}

매독균은 배양이나 염색이 어려워서 혈청학적 검사가 매독 감염의 진단에 이용되고 있다. 매독의 혈청학적 검사에는 리포 이드성 항원을 사용하여 카디오리핀, 레시틴, 콜레스테롤을 검 사하는 비트레포네마 검사와 매독균 항원을 사용하여 항 매독 균 항체를 검사하는 트레포네마 검사가 있다[1]. 그리고 이러 한 혈청학적 검사를 이용하여 진단을 하는 알고리즘들이 개발 되어 진단의 정확성과 효율성을 높이기 위한 연구들이 진행되 어 왔다[2,3]. 이러한 매독혈청검사 중 수기법은 노동력 소모
가 많고 결과 판정 시 객관성에 문제가 있을 수 있어 최근 효 소면역법, 화학발광면역법 등의 원리를 이용하여 간단하고 신 속하게 매독혈청검사를 할 수 있는 자동화된 검사들이 개발되 었다[4-8]. 본 연구에서는 라텍스 응집 면역혼탁법을 이용한 매독항체 측정시약 중 rapid plasma reagin (RPR) 검사시약 AutoLab RPR (IVD-RPR; IVDLab Co., Uiwang, Korea)과 Treponema pallidum Latex Agglutination (TPLA) 검사시 약인 AutoLab TPLA (IVD-TPLA, IVDLab Co.)를 평가하고, 기존에 사용하던 자동화 시약과 검사결과를 비교해보았다. 


\section{재료 및 방법}

\section{1. 검사대상과 검사방법}

검사 간 비교를 위해 2013년 12월부터 2014년 5월까지 가 천대길병원에 내원하여 $\mathrm{RPR}$ 검사를 의뢰했던 환자들 중 남 은 혈청 검체의 양이 $1.5 \mathrm{~mL}$ 이상이며, 육안적 용혈이 없는 환 자 122 명을 선정하였다. 대상군은 남자 59 명, 여자 63명이었 으며, 연령 분포는 7세에서 87세였고 중간 값은 46세였다. 총 122 명의 환자 중 14 명 $(11.47 \%)$ 은 일차 매독이 의심되는 환 자, 3 명 $(2.42 \%)$ 은 이차 매독이 의심되는 환자, 13 명 $(10.65 \%)$ 은 잠복 매독이 의심되는 환자, 19명 (15.57\%)은 과거 매독 진 단 후 치료가 완료되거나 치료 중인 환자, 65 명 $(52.42 \%)$ 은 매 독 감염의 과거력이 없고 현증도 없는 환자, 8 명 $(6.45 \%)$ 은 현 증은 없으나 의무기록이 충분하지 않아서 과거력에 대한 정보 조사가 제대로 이루어지지 않은 unknown군이었다. 선정된 환 자의 검체는 원심분리 후 즉시 혈청을 분리하여 $-70^{\circ} \mathrm{C}$ 에서 냉 동 보관하였다. 본 연구는 가천대길병원 산하의 연구윤리위원 회에서 연구과정을 검토받았다. 모든 검체에서 RPR 검사시약 인 Hisens Auto RPR LTIA (HBi-RPR; HBi Co., Anyang, Korea)과 IVD-RPR, TPLA 검사시약인 Hisens Auto TP LTIA (HBi-TPLA, HBi Co.)과 IVD-TPLA을 사용하여 매 독 검사를 실시하였다. 검사는 모두 자동화 장비인 $\mathrm{ADVIA}$ 2400 (Siemens Healthcare, Camberley, UK)에서 시행하였 다. $\mathrm{HBi}-\mathrm{RPR}$ 과 IVD-RPR 시약의 검사원리는 카디오리핀, 레시틴 항원을 라텍스입자에 감작하여 라텍스 면역비탁법으 로 매독지질항체를 검출하는 것이며, 두 키트의 양성 판정기준 은 제조업체의 권장에 따라 $1.0 \mathrm{U}$ (unit) 이상일 때로 정하였 다. $\mathrm{HBi}-\mathrm{TPLA}$ 와 IVD-TPLA의 검사원리는 트레포네마 항원 을 라텍스 입자에 감작하여 항트레포네마 항체를 검출하는 것
이며, 제조업체의 권장에 따라 HBi-TPLA 시약의 경우 $20 \mathrm{U}$, IVD-TPLA 시약의 경우 $10 \mathrm{U}$ 이상일 때 양성으로 판정하였 다. 냉동 보관되었던 검체는 한번 해동 후 모든 검사를 동시에 시행하였다.

\section{AutoLab RPR (IVD-RPR)과 AutoLab TPLA (IVD-TPLA) 시약의 평가}

$\mathrm{HBi}-\mathrm{RPR}$, IVD-RPR, 그리고 IVD-TPLA 시약을 대상으로 정밀도 평가를 시행하였다. 양성 정도관리물질(IVDLab Co.) 을 이용하여 20회를 동시에 검사하여 검사차례 내(withinrun) 정밀도를 확인하였고, 1 회 2번, 하루 2회씩 5 일 동안 총 20 회 측정하여 총 정밀도를 평가하였다. $\mathrm{RPR}$ 검사의 경우 양 성판정치인 $1 \mathrm{U}$ 과 가까운 값의 정밀도를 알아보기 위해 양성 과 음성 정도관리물질(IVDLab Co.)을 1:1로 섞은 물질로 위 와 같은 방법으로 검사차례 내 정밀도와 총 정밀도를 알아보 았다. 직선성은 $\mathrm{RPR}$ 과 $\mathrm{TPLA}$ 검사상 고농도 양성결과를 보 인 환자의 검체 $(\mathrm{RPR} 8.0 \mathrm{R}$, TPLA $524.6 \mathrm{U})$ 와 저농도 검체 (RPR 0.0 U, TPLA 0.0 U)를 5가지 농도로 혼합하여(0:4, $1: 3,2: 2,3: 1,4: 0)$ 측정하였다. 검출한계는 공시료에 해당하 는 음성 정도관리물질과 저농도 검체를 각각 20 회 측정하여 $\mathrm{EP} 17-\mathrm{A}$ 에서 제시하는 공식에 따라 정하였다[검출한계=공 시료의 평균 $+1.645 \times($ 공시료의 표준편차 $)+1.645 \times($ 저농도 검체의 표준편차)]. 정밀도 평가는 Clinical and Laboratory Standards Institute (CLSI) guideline EP15-A2, 직선성 평 가는 CLSI EP6-A, 검출한계는 EP17-A를 참고하였다[9-11].

\section{3. 두 자동화 검사시약의 비교}

기존 검사법과의 비교는 $\mathrm{HBi}-\mathrm{RPR}$ 과 IVD-RPR 시약 사이 의 검사결과, $\mathrm{HBi}-\mathrm{TPLA}$ 와 IVD-TPLA 시약의 검사결과의

Table 1. Precision of HBi-RPR, IVD-RPR, and IVD-TPLA

\begin{tabular}{|c|c|c|c|c|c|c|}
\hline & \multicolumn{3}{|c|}{ Within-run precision } & \multicolumn{3}{|c|}{ Total precision } \\
\hline & Mean (U) & $\mathrm{SD}(\mathrm{U})$ & CV (\%) & Mean (U) & $\mathrm{SD}(\mathrm{U})$ & CV (\%) \\
\hline \multicolumn{7}{|l|}{ HBi-RPR } \\
\hline Positive+negative control & 0.84 & 0.28 & 33.33 & 1.00 & 0.40 & 40.00 \\
\hline \multicolumn{7}{|l|}{ IVD-RPR } \\
\hline Positive+negative control & 1.08 & 0.08 & 7.41 & 1.00 & 0.07 & 7.00 \\
\hline \multicolumn{7}{|l|}{ IVD-TPLA } \\
\hline Positive control & 69.80 & 0.30 & 0.43 & 69.10 & 3.40 & 4.92 \\
\hline
\end{tabular}

Abbreviations: RPR, rapid plasma reagin; TPLA, Treponema pallidum latex agglutination. 
Mi-Jung Park et al • Evaluation of AutoLab RPR and AutoLab TPLA

일치율을 알아보았으며, 일치하지 않는 경우 환자의 의무기록 과 fluorescent treponemal antibody-absorption (FTA-ABS) $\mathrm{IgM}$ 과 FTA-ABS IgG 결과를 검토하였다. 임상 진단은 증 상 및 병력, 매독의 혈청 검사결과를 종합적으로 고려하였다. $\mathrm{RPR}$ 검사와 TPLA 검사들 사이의 불일치 검체들 중에서 남은 검체의 양이 $500 \mathrm{mcL}$ 이상인 경우 FTA-ABS IgM과 FTA$\mathrm{ABS} \operatorname{IgG}$ 검사를 시행하였다. FTA-ABS IgM과 FTA-ABS $\mathrm{IgG}$ 검사는 녹십자의료재단에 의뢰하여 FTA-ABS IFA test system (Zeus Scientific Inc., Raritan, NJ, USA)의 시약을 사용하여 제조사의 지침에 따라 검사를 시행하였고, Axioskop (Carl Zeiss, Jena, Germany) 형광현미경을 이용하여 판독하 였다.

\section{결과}

\section{1. 정밀도}

각 시약들의 정밀도는 Table 1에 정리하였다. IVD-RPR 시
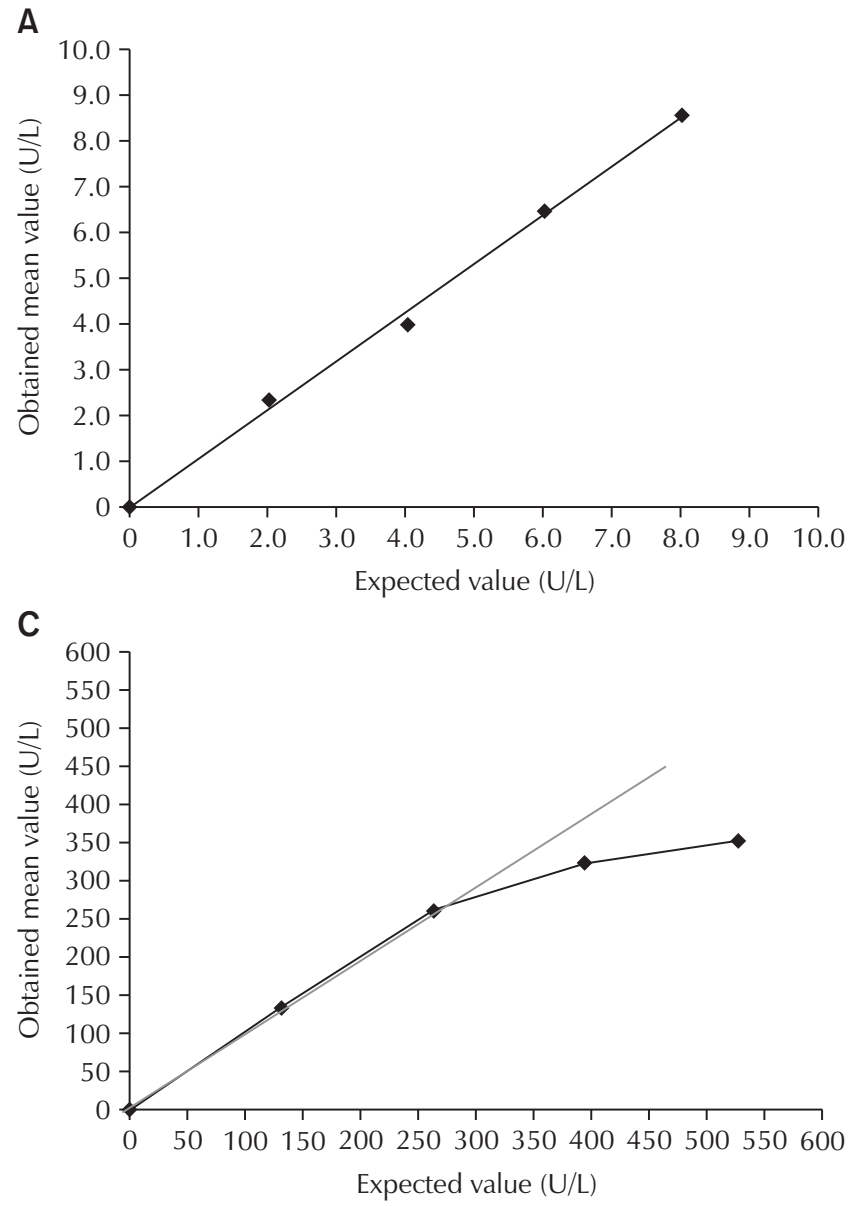

약에서 양성 정도관리물질의 검사차례 내 변이계수는 $3.85 \%$, 총 변이계수는 $7.92 \%$ 였다. IVD-TPLA 시약에서 양성 정도 관리물질에서 검사차례 내 변이계수는 $0.43 \%$, 총 변이계수는 $4.92 \%$ 였다.

\section{2. 직선성}

$\mathrm{IVD}-\mathrm{RPR}$ 시약에서 저농도와 고농도 환자 검체를 5 가지 농 도로 혼합하여 측정한 결과 0-6.0 U의 농도범위 안에서 직선 성을 보였다. IVD-TPLA 시약에서 저농도와 고농도 환자 검 체를 5가지 농도로 혼합하여 측정한 결과 0-260 U의 농도범위 안에서 보고 가능한 직선성을 보였다(Fig. 1).

\section{3. 검출한계}

검출한계치는 각각 IVD-RPR 시약에서 $0.39 \mathrm{U}, \mathrm{IVD}-\mathrm{TPLA}$ 시약에서 $2.56 \mathrm{U}$ 였다.
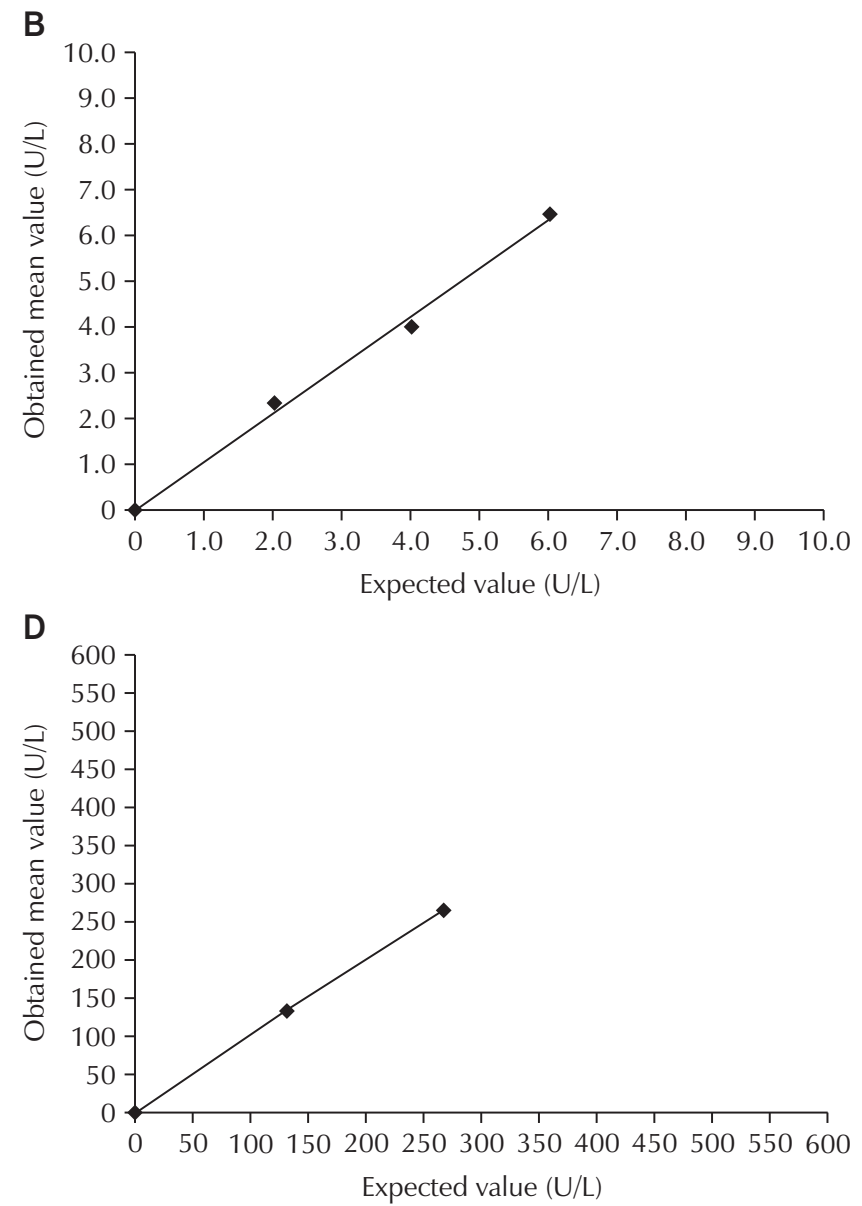

Fig. 1. Linearity of (A, B) the IVD-RPR test and (C, D) the IVD-TPLA test. 
Journal of LABORATORY MEDICINE and QUALITY ASSURANCE

Mi-Jung Park et al • Evaluation of AutoLab RPR and AutoLab TPLA

Table 2. Number of positive-result samples per assay kit

\begin{tabular}{lcccrr}
\hline \multicolumn{1}{c}{ Syphilis } & Total no. & HBi-RPR & IVD-RPR & HBi-TPLA & IVD-TPLA \\
\hline Primary & 14 & $14(100.00)$ & $13(92.86)$ & $12(85.71)$ & $14(100.00)$ \\
Secondary & 3 & $3(100.00)$ & $3(100.00)$ & $3(100.00)$ & $3(100.00)$ \\
Latent & 13 & $11(84.62)$ & $8(61.54)$ & $13(100.00)$ & $13(100.00)$ \\
History of treated syphilis & 19 & $15(78.95)$ & $3(15.79)$ & $19(100.00)$ & $19(100.00)$ \\
No history of syphilis & 65 & $1(1.54)$ & $1(1.54)$ & 0 & $7(1.54)$ \\
Unknown & 8 & $2(25.00)$ & 0 & $5(100.00)$ \\
Total & 122 & 46 & 28 & 54 & 58 \\
\hline
\end{tabular}

Values are presented as number (\%).

Abbreviations: RPR, rapid plasma reagin; TPLA, Treponema pallidum latex agglutination.

Table 3. Comparison of results obtained with HBi-RPR and IVD-RPR (cut-off: $1.0 \mathrm{U}$ )

\begin{tabular}{lccc}
\hline \multirow{2}{*}{ HBi-RPR } & \multicolumn{2}{c}{ IVD-RPR } & Total \\
\cline { 2 - 3 } & Non-reactive & Reactive & \\
\hline Non-reactive & 75 & 1 & 76 \\
Reactive & 19 & 27 & 46 \\
Total & 94 & 28 & 122 \\
\hline
\end{tabular}

Abbreviation: RPR, rapid plasma regain.

\section{4. 검사 간 비교}

\section{1) 환자군의 특징}

각 환자군에서 RPR과 TPLA 검사의 시약별 양성률은 Table 2에 정리하였다. $\mathrm{HBi}-\mathrm{RPR}$ 시약을 이용한 검사는 과거 감염 후 치료 완료되었거나 치료 중인 환자군에서 IVD-RPR 시약보다 높은 양성률을 보였다(HBi-RPR 78.95\%, IVD$\mathrm{RPR} 15.79 \%$ ). TPLA의 경우 이차 매독, 잠복 매독, 과거 매 독 환자군에서는 일치하는 결과를 보였다.

\section{2) 시약 간의 결과 일치율}

$\mathrm{HBi}-\mathrm{RPR}$ 시약과 IVD-RPR 시약의 결과 일치율은 $83.60 \%$ (102/122)이었다(Table 3). HBi-TPLA 시약과 IVD-TPLA 시약의 결과 일치율은 $96.72 \%$ (118/122)였다(Table 4).

\section{3) 불일치 건수의 환자 분포}

불일치 건수의 환자 분포와 검사결과는 Table 5 에 정리하였 다. RPR 검사는 매독의 과거 감염 후 치료 완료되었거나 치료 중인 환자군에서 많은 불일치를 보였으며(12/19, 63.15\%), 모 두 $\mathrm{HBi}-\mathrm{RPR}$ 시약에서 양성, IVD-RPR 시약에서 음성을 보 였다.
Table 4. Comparison of results obtained with HBi-TPLA and IVD-TPLA (cut-off: $20 \mathrm{U}$ for HBi-TPLA and $10 \mathrm{U}$ for IVDTPLA)

\begin{tabular}{lccc}
\hline \multirow{2}{*}{ HBi-TPLA } & \multicolumn{2}{c}{ IVD-TPLA } & \multirow{2}{*}{ Total } \\
\cline { 2 - 3 } & Non-reactive & Reactive & \\
\hline Non-reactive & 64 & 4 & 68 \\
Reactive & 0 & 54 & 54 \\
Total & 64 & 58 & 122 \\
\hline
\end{tabular}

Abbreviation: TPLA, Treponema pallidum latex agglutination.

4) 불일치 환자의 $\mathrm{FTA}-\mathrm{ABS} \operatorname{lgM}$ 과 $\operatorname{lgG}$ 의 결과

총 23 명의 불일치 결과 검체 중 20 검체에서 $\mathrm{FTA}-\mathrm{ABS}$ IgM 검사를, 19 검체에서 FTA-ABS IgG 검사를 시행할 수 있었다 (Table 5). FTA-ABS IgM 검사에서는 일차매독이 의심되는 환자 중 한 명에서만 양성을 보였다. FTA-ABS IgG 검사결과 는 IVD-TPLA 검사결과와 일치하였다.

\section{고찰}

일반적으로 검사실에서는 다량의 검사를 정해진 시간 내 에 수행해야 하는 목표를 이루기 위해 정확성과 신속성을 갖 춘 검사법을 요구하고 있다. 매독 감염의 혈청학적 검사 역시 이러한 목적에 맞게 기존의 수기법을 대체할 자동화 검사키트 가 개발되어왔다 [6-8,12]. 일본에서는 라텍스 응집 면역혼탁 법(turbidimetry)을 이용한 자동화된 시약들이 개발되었는데, 비트레포네마 검사와 트레포네마 검사가 모두 가능하고 자동 화 장비에서 측정이 가능하다. 이러한 자동화 검사들은 수기법 과 비교하였을 때 결과의 상관성을 보여 유용한 것으로 나타났 지만, 자동화 검사들 간의 결과 값의 상관성이 낮아서 정량검 사로서의 유용성을 밝히기 위해서는 더 많은 연구가 필요하다 〔13]. 자동화 검사키트 시약 간의 민감도와 결과 값의 차이는 
Journal of LABORATORY MEDICINE and QUALITY ASSURANCE

Mi-Jung Park et al • Evaluation of AutoLab RPR and AutoLab TPLA

Table 5. Discrepant results obtained with the RPR and TPLA tests

\begin{tabular}{|c|c|c|c|c|c|c|c|c|c|}
\hline Variable & Sex & $\begin{array}{l}\text { Age } \\
\text { (yr) }\end{array}$ & $\begin{array}{l}\text { HBi-RPR } \\
(\mathrm{U})\end{array}$ & $\begin{array}{l}\text { IVD-RPR } \\
\quad(\mathrm{U})\end{array}$ & $\begin{array}{l}\text { HBi-TPLA } \\
\quad(\mathrm{U})\end{array}$ & $\begin{array}{l}\text { IVD-TPLA } \\
(\mathrm{U})\end{array}$ & $\begin{array}{c}\text { History of } \\
\text { syphilis }\end{array}$ & $\begin{array}{l}\text { FTA-ABS } \\
\text { IgM }\end{array}$ & $\begin{array}{l}\text { FTA-ABS } \\
\text { IgG }\end{array}$ \\
\hline \multicolumn{10}{|c|}{$\begin{array}{l}\text { HBi-RPR(+)/IVD-RPR(-) } \\
\text { samples }\end{array}$} \\
\hline & $\mathrm{M}$ & 48 & 5.2 & 0.5 & 126.0 & 226.7 & Primary syphilis & Negative & Positive \\
\hline & $\mathrm{F}$ & 44 & 5.3 & 0.5 & 547.0 & 352.6 & Latent syphilis & Negative & Positive \\
\hline & $\mathrm{F}$ & 22 & 4.1 & 0.6 & 491.0 & 381.9 & Latent syphilis & Negative & Positive \\
\hline & $\mathrm{F}$ & 22 & 4.3 & 0.7 & 486.0 & 381.2 & Latent syphilis & Negative & Positive \\
\hline & $\mathrm{F}$ & 40 & 2.2 & 0.6 & 684.0 & 240.7 & History of syphilis & Negative & NA \\
\hline & $\mathrm{M}$ & 25 & 6.0 & 0.4 & 668.0 & 392.6 & History of syphilis & Negative & Positive \\
\hline & $\mathrm{M}$ & 34 & 4.4 & 0.5 & 507.0 & 343.4 & History of syphilis & Negative & Positive \\
\hline & $\mathrm{F}$ & 70 & 1.2 & 0.9 & 121.0 & 249.0 & History of syphilis & Negative & Positive \\
\hline & $\mathrm{F}$ & 21 & 1.3 & 0.6 & 610.0 & 322.6 & History of syphilis & Negative & Positive \\
\hline & $\mathrm{F}$ & 23 & 1.6 & 0.6 & 450.0 & 365.0 & History of syphilis & NA & NA \\
\hline & $\mathrm{F}$ & 31 & 1.6 & 0.9 & 642.0 & 374.5 & History of syphilis & Negative & Positive \\
\hline & $\mathrm{M}$ & 33 & 1.2 & 0.7 & 643.0 & 340.3 & History of syphilis & Negative & Positive \\
\hline & $\mathrm{M}$ & 23 & 1.7 & 0.8 & 663.0 & 357.9 & History of syphilis & Negative & Positive \\
\hline & $\mathrm{M}$ & 23 & 1.3 & 0.6 & 645.0 & 363.2 & History of syphilis & Negative & Positive \\
\hline & $\mathrm{F}$ & 70 & 1.0 & 0.9 & 132.0 & 324.8 & History of syphilis & Negative & Positive \\
\hline & $\mathrm{M}$ & 40 & 1.5 & 0.5 & 702.0 & 268.0 & History of syphilis & Negative & Positive \\
\hline & M & 87 & 2.1 & 0.5 & 194.0 & 361.5 & Unknown & Negative & Positive \\
\hline & $\mathrm{F}$ & 58 & 2.8 & 0.5 & 133.0 & 30.5 & Unknown & Negative & Positive \\
\hline \multicolumn{10}{|c|}{$\begin{array}{l}\mathrm{HBi}-\mathrm{RPR}(-) / \mathrm{IVD}-\mathrm{RPR}(+) \\
\text { samples }\end{array}$} \\
\hline & $\mathrm{F}$ & 30 & 0.1 & 2.8 & 1.0 & 0.3 & None & Negative & Negative \\
\hline \multicolumn{10}{|c|}{$\begin{array}{l}\text { HBi-TPLA(-)/IVD-TPLA(+) } \\
\text { samples }\end{array}$} \\
\hline & $\mathrm{M}$ & 21 & 2.0 & 5.1 & 7.0 & 63.8 & Primary syphilis & Positive & Positive \\
\hline & $\mathrm{F}$ & 56 & 1.1 & 1.1 & 12.0 & 48.3 & Primary syphilis & NA & NA \\
\hline & $\mathrm{F}$ & 68 & 0 & 0.2 & 1.0 & 53.2 & Unknown & Negative & Positive \\
\hline \multicolumn{10}{|c|}{$\begin{array}{l}\text { HBi-RPR(+)/IVD-RPR(-) and } \\
\text { HBi-TPLA(-)/IVD-TPLA(+) } \\
\text { samples }\end{array}$} \\
\hline & $\mathrm{F}$ & 59 & 5.8 & 0.1 & 5.0 & 25.4 & None & NA & NA \\
\hline
\end{tabular}

Abbreviations: RPR, rapid plasma reagin; TPLA, Treponema pallidum latex agglutination; FTA-ABS, fluorescent treponemal antibodyabsorption; NA, not available.

시약재료의 차이 등을 원인으로 생각할 수 있다[14].

본 연구에서는 라텍스 응집 면역혼탁법 원리를 이용한 IVD$\mathrm{RPR}$ 과 IVD-TPLA를 평가하였다. 직선성과 검출한계에서 두 시약 모두 검사에 적정한 결과를 보였다. 정밀도의 경우 양 성 정도관리물질 값에서의 정밀도는 검사차례 내와 총 정밀 도 모두 두 시약에서 $10 \%$ 이내의 CV를 보여 우수하다고 평가 할 수 있다. FTA-ABS IgG와 IgM 검사는 모든 환자에서 시
행하지 못하였지만, FTA-ABS IgG 검사는 시행했던 19검체 모두 TPLA 검사결과와 일치하였으며, FTA-ABS IgM 검사 는 일차매독 환자 두 명 중 한 명에서만 양성, 잠복매독 환자에 서는 모두 음성을 보였다. 이 연구에서 의무기록이 부족했던 unknown군에 해당하는 환자들은 TPLA의 두 시약에서 모두 양성 결과를 보이거나 또는 FTA-ABS IgG가 양성으로 매독 의 과거 감염이 의심되는 환자들이었다. 
Mi-Jung Park et al • Evaluation of AutoLab RPR and AutoLab TPLA

이번 연구에서 $\mathrm{RPR}$ 검사의 두 시약 간의 결과 일치율은 $83.6 \%$ 로 비교적 낮은 것으로 나타났다. 불일치 결과 중 대부 분(95\%, 19/20)은 HBi-RPR에서 양성을 보이나 IVD-RPR 에서는 음성을 보이는 결과였다. 이 19 명의 불일치 결과 환자 들의 병력을 보면 일차매독이 의심되는 환자와 잠복매독이 의 심되는 검체가 4건으로 이 경우에는 $\mathrm{HBi}-\mathrm{RPR}$ 시약이 더 많 이 검출한 것으로 보인다. 그러나 매독이 의심되지 않는 환자 3 명과 매독 치료의 과거력이 있는 12 명의 환자에서 $\mathrm{HBi}-\mathrm{RPR}$ 만 양성인 사례에서는 $\mathrm{HBi}-\mathrm{RPR}$ 시약의 결과가 위양성일 가 능성이 높다. 이전 연구에서 자동화 $\mathrm{RPR}$ 검사에서 양성 판 정치로 $1.0 \mathrm{RU}$ 를 사용할 경우 수기법 RPR보다 양성률이 높 고 위양성이 빈번하다는 결과를 보였다[5]. 그러나 다른 자동 화 매독 검사를 이용한 이전 연구에 따르면 자동화 매독 검사 키트의 결과가 수기법과의 일치율도 높고, 수기법 RPR에 비 해 치료 후 더 빠르게 감소하여 자동화 RPR 검사가 매독 치료 후 모니터링에서 유용하였다[15]. 따라서 검사실마다 적절한 판정기준치를 정하면 매독 환자의 진단과 모니터링에 자동화 $\mathrm{RPR}$ 이 유용하게 쓰일 수 있을 것으로 보인다. 이 연구에서도 4건의 일차매독과 잠복매독의 환자에서 진단율을 높이기 위 해서 IVD-RPR 시약의 양성 판정치를 검사실 내에서 재설정 한 후 사용하게 되면 유용하게 쓰일 수 있을 것으로 생각된다. $\mathrm{RPR}$ 검사의 불일치 결과 중에 양성 판정치 $1.0 \mathrm{U}$ 근처의 값 이 많이 있었으며, 이에 대한 결과 해석에 도움이 되기 위하여 $1.0 \mathrm{U}$ 근처의 정밀도를 IVD-RPR과 $\mathrm{HBi}-\mathrm{RPR}$ 시약에서 평 가하였다. 이 결과 IVD-RPR 시약의 검사차례 내 정밀도와 총 정밀도가 모두 $\mathrm{HBi}-\mathrm{RPR}$ 시약보다 좋은 결과를 보였다(Table 1). RPR 검사의 불일치 결과를 보인 환자들이 많은 수가 매독 의 과거감염 환자인 것을 고려하여 RPR의 음성화를 확인하는 데에는 IVD-RPR 시약이 더 유용할 수 있을 것으로 생각된다. 또한 이러한 결과를 볼 때 시약 평가 시 양성 판정치 근처의 정 밀도 평가도 중요한 정보를 제공할 수 있다는 것을 보여주었 다. 양성 판정치 근처 값에서의 정밀도가 적절하지 못한 경우 에는 양성 판정치 근처의 약한 양성인 경우 재검을 반드시 시 행하여 위양성을 예방해야 할 것으로 생각된다.

TPLA 검사의 두 시약 간의 불일치 결과는 모두 HBi-TPLA 에서 음성이지만 IVD-TPLA에서 양성인 건수였다. 이 중 두 사례는 초기매독이 의심되는 환자이고, 두 환자는 과거매독 의 과거력을 밝히지는 못한 환자들이었다. IVD-TPLA 시약이 $\mathrm{HBi}-\mathrm{TPLA}$ 시약보다 민감하다고 볼 수 있으며, 초기매독 진 단에는 IVD-TPLA 시약이 더 유용한 것으로 생각된다.

이 연구의 제한점은 환자기록에 의존하여 병력을 조사하여 매독 감염의 과거력 여부가 부정확할 수 있다는 점이다. 또한
검체를 냉동 보관 후 각각 다른 보관기간을 거쳐 검사에 쓰였 으며, 검체 양의 한정으로 인해 검사를 두 번 이상 중복검사를 하지 못하였다.

결론적으로 IVD-RPR과 IVD-TPLA 시약의 직선성, 검출 한계, 양성 정도관리물질에서의 정밀도는 매독의 진단을 위한 검사로서 적절한 수준을 나타내었다. 특히 IVD-RPR은 $\mathrm{HBi}^{-}$ $\mathrm{RPR}$ 보다 양성 판정치 근처의 정밀도가 좋은 것으로 나타났으 며, 매독의 모니터링에서 RPR 값의 음성화를 확인하는 데에 는 더 좋을 것으로 생각된다. 그러나 $\mathrm{HBi}-\mathrm{RPR}$ 시약에서 초 기매독과 잠복매독 환자의 양성률이 더 좋았다. 따라서 IVD$\mathrm{RPR}$ 검사의 양성 판정치를 검사실 내에서 재정립한 후 매 독 환자의 진단과 모니터링에 적절하게 사용할 수 있을 것으 로 생각된다. 또한 시약의 정밀도 평가를 양성 판정치 근처의 값에서 평가해 보는 것도 도움이 되는 것으로 생각된다. IVDTPLA의 경우 HBi-TPLA보다 초기매독 환자에서 좋은 민감도 를 보여 매독의 진단에 유용하게 쓰일 수 있을 것으로 보인다.

\section{REFERENCES}

1. Larsen SA, Steiner BM, Rudolph AH. Laboratory diagnosis and interpretation of tests for syphilis. Clin Microbiol Rev 1995;8:1-21.

2. Lipinsky D, Schreiber L, Kopel V, Shainberg B. Validation of reverse sequence screening for syphilis. J Clin Microbiol 2012;50:1501.

3. Tong ML, Lin LR, Liu LL, Zhang HL, Huang SJ, Chen YY, et al. Analysis of 3 algorithms for syphilis serodiagnosis and implications for clinical management. Clin Infect Dis 2014;58:1116-24.

4. Marangoni A, Moroni A, Accardo S, Cevenini R. Laboratory diagnosis of syphilis with automated immunoassays. J Clin Lab Anal 2009;23:1-6.

5. Kim HS, Lee YK, Kang HJ. Serologic test for syphilis by mediace RPR test for chemistry autoanalyzer. J Lab Med Qual Assur 2007;29:195-9.

6. Castro R, Prieto ES, Santo I, Azevedo J, Exposto Fda L. Evaluation of an enzyme immunoassay technique for detection of antibodies against Treponema pallidum. J Clin Microbiol 2003;41:250-3.

7. Farshy CE, Hunter EF, Helsel LO, Larsen SA. Fourstep enzyme-linked immunosorbent assay for detection of Treponema pallidum antibody. J Clin Microbiol 


\section{Journal of LABORATORY MEDICINE and QUALITY ASSURANCE}

Mi-Jung Park et al • Evaluation of AutoLab RPR and AutoLab TPLA

1985;21:387-9.

8. Sampedro-Martinez A, Padilla-Malo A, Gomez-Camarasa C, Rodriguez-Granger J, Lara-Oya A. Evaluation of a new chemiluminescence immunoassay for laboratory diagnosis of syphilis. J Microbiol Methods 2013;94:133-4.

9. National Committee for Clinical Laboratory Standards. User verification of performance for precision and trueness: approved guideline EP15-A2. Wayne (PA): National Committee for Clinical Laboratory Standards, 2005.

10. National Committee for Clinical Laboratory Standards. Evaluation of the linearity of quantitative measurement procedures: a statistical approach: approved guideline EP6-A. Wayne (PA): National Committee for Clinical Laboratory Standards, 2003.

11. National Committee for Clinical Laboratory Standards. Protocols for determination of limits of detection and limits of quantitation: approved guideline EP17-A. Wayne (PA): National Committee for Clinical Laboratory Stan- dards, 2004.

12. Schmidt BL, Edjlalipour M, Luger A. Comparative evaluation of nine different enzyme-linked immunosorbent assays for determination of antibodies against Treponema pallidum in patients with primary syphilis. J Clin Microbiol 2000;38:1279-82.

13. Onoe T, Honda M, Matsuo K, Sasaki H, Sawamura M, Onoe Y, et al. Examination of the correlation between the manual and automated serological testing methods for syphilis. J Dermatol 2012;39:355-61.

14. Castro AR, Morrill WE, Shaw WA, Gale DC, Park MM, Peregrino-Ferreira LA, et al. Use of synthetic cardiolipin and lecithin in the antigen used by the venereal disease research laboratory test for serodiagnosis of syphilis. Clin Diagn Lab Immunol 2000;7:658-61.

15. Moon H, Huh J, Lee M, Chung W. Evaluation of IMMUNOTICLES Auto3RPR and Auto3TP for testing of syphilis infection. J Lab Med Qual Assur 2007;29:259-65. 
매독 검사를 위한 AutoLab Rapid Plasma Reagin과 AutoLab Treponema pallidum Latex Agglutination 시약의 평가 박미정 • 박필환 • 서일혜・안정열・김경희・서자영 • 정지훈 • 김문진 • 이환태 가천대길병원 진단검사의학과

배경: 최근 매독 감염의 효율적인 진단을 위해 자동화 혈청 검사법이 개발되었다. 이 연구에서는 매독 의 혈청 검사를 위한 새로운 자동화 검사시약을 평가해 보고자 한다.

방법: 면역비탁법을 이용한 자동화 검사시약인 AutoLab (rapid plasma regain) RPR (IVD-RPR) 와 AutoLab (Treponema pallidum Latex Agglutination) TPLA (IVD-TPLA) (둘 다 IVDLab Co., Korea) 시약의 정밀도, 직선성, 그리고 검출한계를 측정하였다. 또한 다른 자동화 검사시약인 Hisens Auto RPR LTIA (HBi-RPR)와 Hisens Auto TP LTIA (HBi-TPLA) (둘 다 HBi Co., Korea)에서 검 체 122 개를 이용하여 결과를 비교해 보았다.

결과: IVD-RPR과 IVD-TPLA 시약은 양성 정도관리물질(IVDLab Co.)을 이용한 정밀도 평가에서 변이계수 $10 \%$ 이내의 적절한 정밀도를 보였다. RPR 검사의 양성 판정치 근처에서는 IVD-RPR 시 약의 정밀도가 $\mathrm{HBi}-\mathrm{RPR}$ 시약의 정밀도보다 검사차례 내 변이계수와 총 변이계수 모두 우수한 결 과를 보였다(CV, 7.0-7.4\% for IVD-RPR; CV, 33.3-40.0\% for HBi-RPR). IVD-RPR과 IVDTPLA 시약은 매독 검사를 위한 적절한 직선성과 검출한계를 보였다. IVD-RPR 시약과 HBi-RPR 시약 간의 결과 일치율은 83.6\% (102건/122건)이었으며, 불일치 건수 중 대부분(19건/20건)은 $\mathrm{HBi}-\mathrm{RPR}$ 은 양성이며 IVD-RPR은 음성인 결과를 보였다. 이 중 12건은 과거 매독 감염 후 치료받은 환자들이었다. IVD-TPLA와 HBi-TPLA 검사의 일치율은 96.72\% (118건/122건)이었으며, 총 4건 의 불일치 결과는 모두 IVD-TPLA는 양성이나 HBi-TPLA는 음성이었다.

결론: IVD-RPR과 IVD-TPLA 시약은 매독 감염의 혈청 검사를 위하여 적절한 정밀도, 직선성, 검출 한계를 보였다. IVD-RPR 시약은 양성 판정치에서 적절한 정밀도를 보이며 매독 감염의 모니터링에 적절히 쓰일 수 있을 것으로 보인다. IVD-TPLA 시약은 일차매독 환자의 진단에 유용하게 쓰일 수 있 을 것으로 생각된다.

(J Lab Med Qual Assur 2015;37:29-36) 